Check for updates

Cite this: RSC Adv., 2019, 9, 2002

Received 29th October 2018

Accepted 4th January 2019

DOI: $10.1039 / c 8 r a 08943 d$

rsc.li/rsc-advances

\section{Photoisomerization and thermal isomerization of ruthenium aqua complexes with chloro-substituted asymmetric bidentate ligands $\uparrow$}

\author{
Masanari Hirahara, (D) *a Hiroki Goto, ${ }^{a}$ Rei Yamamoto, ${ }^{a}$ Masayuki Yagi iD b \\ and Yasushi Umemura ${ }^{a}$
}

A series of ruthenium complexes with chloro-substituted bidentate ligands, proximal- $[\mathrm{Ru}(\mathrm{tpy})(\mathrm{Cl}-\mathrm{pyqu}) \mathrm{L}]^{\mathrm{n}+}$ [ $n=1$ for $\mathrm{L}=\mathrm{Cl}$, and $n=2$ for $\mathrm{L}=\mathrm{OH}_{2}$, tpy $=2,2^{\prime} ; 6^{\prime}, 2^{\prime \prime}$-terpyridine, pyqu $=2$-( $2^{\prime}$ - pyridyl)quinoline] were synthesized and their reversible photoisomerizations and thermal isomerizations were investigated experimentally. The crystal structures of the complexes indicated that introduction of a chloro substituent at the 4- or $4^{\prime}$-position of the pyqu ligand did not change the structure around the metal center from that of the non-substituted complex, proximal-[Ru(tpy)(pyqu)L] ${ }^{n+}$. In contrast, the $6^{\prime}-$ substituted complexes had sterically hindered environments around the metal center. The ruthenium aqua complexes showed reversible photoisomerization between the proximal and distal isomers. The quantum yield for photoisomerization of the $6^{\prime}$-substituted ruthenium aqua complex was almost twice as large as those of the other derivatives. This is explained by weakening of the ligand field on the ruthenium center by introduction of a chloro substituent at the $6^{\prime}$-position. Thermal back isomerization from the distal isomer to the proximal one was observed for the $6^{\prime}$-substituted complex, but such reactions were not observed for the other derivatives. The steric hindrance in the $6^{\prime}$-substituted aqua complex enhanced both thermal isomerization and photoisomerization.

\section{Introduction}

Photoresponsive ruthenium complexes with photolabile monodentate ligand(s) are of interest because of their catalytic activities, bioactivities, and photochemical and electrochemical properties. ${ }^{1}$ These complexes are excited by visible light to metal-to-ligand charge-transfer $\left({ }^{1} \mathrm{MLCT}\right)$ states, and then relax to ${ }^{3}$ MLCT states via rapid intersystem crossing. ${ }^{2}$ The ${ }^{3}$ MLCT excited states are responsible for thermal excitation to metalcentered $\left({ }^{3} \mathrm{MC}\right)$ excited states, which leads photodissociation of a labile ligand to give five-coordinated intermediates (Scheme 1). ${ }^{3}$ Recoordination of a ligand to the intermediate results in photosubstitution or photoisomerization reactions. Electronic and structural effects on the photolabilities of polypyridyl ruthenium complexes in photosubstitution have been extensively studied. ${ }^{1 c, 4}$ It has been found that the reactivity of a complex is strongly controlled by the energy differences

${ }^{a}$ Department of Applied Chemistry, School of Applied Science, National Defense Academy of Japan, Hashirimizu 1-10-20, Yokosuka, Kanagawa 239-8686, Japan. E-mail: hirahara@nda.ac.jp

${ }^{b}$ Department of Materials Science and Technology, Faculty of Engineering, Niigata University, 8050 Ikarashi-2, Niigata 950-2181, Japan

$\dagger$ Electronic supplementary information (ESI) available: Molecular orbitals, absorption and ${ }^{1} \mathrm{H}$ NMR spectra, and crystallographic data. CCDC 1546577-1546582. For ESI and crystallographic data in CIF or other electronic format see DOI: $10.1039 / \mathrm{c} 8 \mathrm{ra} 08943 \mathrm{~d}$ between the ${ }^{3}$ MLCT excited states and ${ }^{3}$ MC states. ${ }^{5}$ Steric hindrance around the metal center weaken the ligand field and accelerates photosubstitution by promoting the thermal transition from ${ }^{3}$ MLCT to ${ }^{3} \mathrm{MC}$ states..$^{4 f, 6}$

Photoisomerizations of ruthenium complexes are rarer than photosubstitutions. ${ }^{7}$ The first example was cis-trans isomerization of $\left[\mathrm{Ru}\left(2,2^{\prime} \text {-bipyridine }\right)_{2}\left(\mathrm{OH}_{2}\right)_{2}\right]^{2+}$, reported by Meyer et al. ${ }^{8}$ Linkage isomerizations of dimethyl sulfoxide derivatives have been experimentally and mechanistically studied by Rack

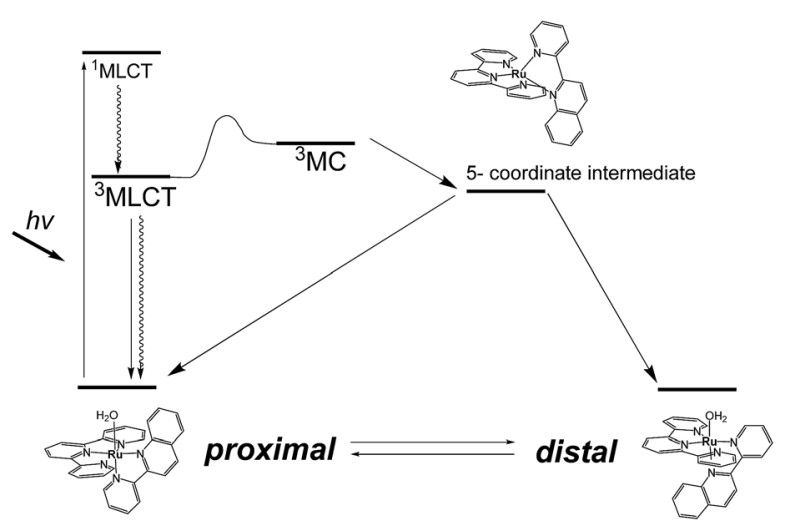

Scheme 1 Energy diagram for photoisomerization of proximal and distal $\left[\mathrm{Ru}\left(\text { tpy) (pyqu) } \mathrm{OH}_{2}\right]^{2+}\right.$. 
et $a l .,{ }^{4 b, 9}$ and were recently used in materials that show lightinduced macroscopic morphological changes. ${ }^{\mathbf{1 0}}$

We have reported irreversible ${ }^{\mathbf{1 1}}$ and reversible ${ }^{\mathbf{1 2}}$ photoisomerizations of mononuclear ruthenium aqua complexes containing asymmetric bidentate ligands. These molecules are important because of their high catalytic activities in water oxidation, which is essential for the development of artificial photosynthesis. ${ }^{13}$ Our experimental and theoretical studies showed that the reversibility of the reaction was controlled by intramolecular hydrogen bonding between an aqua ligand and a pendant moiety of the bidentate ligand (Scheme 1). ${ }^{\mathbf{1 1 b , 1 2 , 1 4}}$ Recently, we used these photoresponsive complexes for morphological control of large molecular assemblies. Ruthenium-complex-based amphiphiles were prepared by introducing two alkyl chains into the tridentate and bidentate ligands. Giant vesicles containing the ruthenium complexes displayed morphological changes under irradiation with red light at $635 \mathrm{~nm}$, i.e., in the phototherapeutic window, and can be used in drug delivery systems. ${ }^{15}$ Investigation of structural and electronic effects on photoisomerization is therefore important for enabling control of the catalytic activities and photoresponsive properties of ruthenium complexes.

In this work, we investigated structural and electronic effects on the reversible photoisomerizations of proximal-[(tpy)(pyqu) $\left.\mathrm{OH}_{2}\right]^{2+}\left(\mathrm{p}-\mathbf{1} \mathbf{H}_{2} \mathbf{O}\right)$ by introducing a chloro substituent on the bidentate pyqu ligand (tpy $=2,2^{\prime} ; 6^{\prime}, 2^{\prime \prime}$-terpyridine, pyqu $=2-\left(2^{\prime}\right.$ pyridyl)quinoline). As shown in Scheme 2, we prepared ruthenium aqua complexes, namely p-2 $\mathbf{H}_{2} \mathbf{O}, \mathrm{p}-\mathbf{3} \mathbf{H}_{2} \mathrm{O}$, and $\mathrm{p}-\mathbf{4} \mathbf{H}_{2} \mathrm{O}$, with a chloro substituent at the $4-4^{\prime}$-, and $6^{\prime}$-positions on the bidentate ligand, respectively. The electron-withdrawing chloro substituent on the pyqu ligand stabilizes the $\pi^{*}$ levels of the complexes. In contrast, based on studies of the photosubstitution of ruthenium complexes, introduction of the chloro substituent at the $6^{\prime}$-position $\left(\mathrm{p}-\mathbf{2} \mathbf{H}_{2} \mathbf{O}\right)$ destabilizes the ${ }^{3} \mathrm{MC}$ state because of structural distortion around the ruthenium center. All the complexes synthesized in this work were fully characterized using X-ray crystallography. The results show that structural distortion strongly affected photoisomerization of the complexes. Additionally, thermal back isomerization was

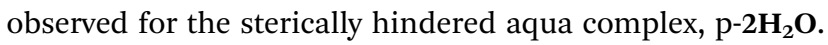
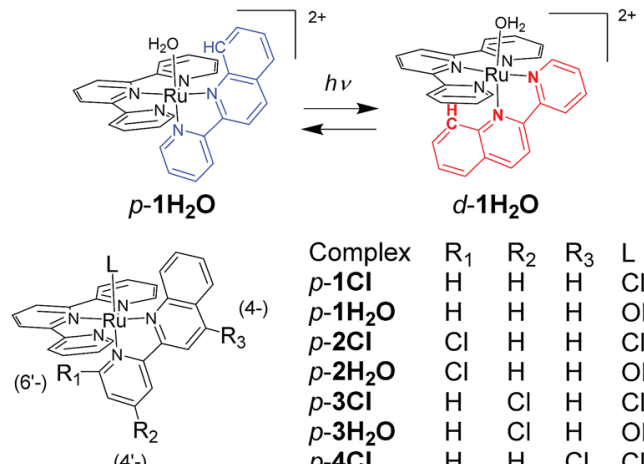

$\begin{array}{lllll}\text { Complex } & \mathrm{R}_{1} & \mathrm{R}_{2} & \mathrm{R}_{3} & \mathrm{~L} \\ p-1 \mathrm{Cl} & \mathrm{H} & \mathrm{H} & \mathrm{H} & \mathrm{Cl} \\ p-1 \mathrm{H}_{2} \mathrm{O} & \mathrm{H} & \mathrm{H} & \mathrm{H} & \mathrm{OH}_{2} \\ p-2 \mathrm{Cl} & \mathrm{Cl} & \mathrm{H} & \mathrm{H} & \mathrm{Cl} \\ p-2 \mathrm{H}_{2} \mathrm{O} & \mathrm{Cl} & \mathrm{H} & \mathrm{H} & \mathrm{OH}_{2} \\ p-3 \mathrm{Cl} & \mathrm{H} & \mathrm{Cl} & \mathrm{H} & \mathrm{Cl} \\ p-3 \mathrm{H}_{2} \mathrm{O} & \mathrm{H} & \mathrm{Cl} & \mathrm{H} & \mathrm{OH}_{2} \\ p-4 \mathrm{Cl} & \mathrm{H} & \mathrm{H} & \mathrm{Cl} & \mathrm{Cl}^{2} \\ p-4 \mathrm{H}_{2} \mathrm{O} & \mathrm{H} & \mathrm{H} & \mathrm{Cl} & \mathrm{OH}_{2}\end{array}$

Scheme 2 Reversible photoisomerization of $\mathrm{p}-1 \mathrm{H}_{2} \mathrm{O}$ (top) and structures of $\mathrm{p}-n \mathrm{Cl}$ and $\mathrm{p}-n \mathrm{H}_{2} \mathrm{O}(n=1-4)$.

\section{Results and discussion}

\section{Synthesis}

Chloro-substituted bidentate ligands were obtained by oxidation of the pyqu ligand with hydrogen peroxide, followed by chlorination with $\mathrm{POCl}_{3}$. Heating a mixture of $\mathrm{Ru}(\mathrm{tpy}) \mathrm{Cl}_{3}$, the bidentate ligand, and a reducing reagent (triethylamine or ascorbic acid) gave a series of ruthenium chloro complexes. In the thermal reactions, the chloro complexes were obtained as mixtures of the proximal and distal isomers. The distal isomers were minor products, based on thin-layer-chromatography and ${ }^{1} \mathrm{H}$ NMR spectra of the crude products. In the ${ }^{1} \mathrm{H}$ NMR spectra of the crude products, the formation of distal isomers was indicated by prominent doublet peaks at 10.0-10.5 ppm with coupling constants of 5-6.5 Hz, which were assigned to the $6^{\prime}$ proton on the pyqu derivatives. The proximal isomer was isolated using silica-gel chromatography or the differences between the solubilities of the proximal and distal isomers in methanol (yields for p-1Cl, p-3Cl, and p-4Cl were 54\%, 20\%, and $45 \%$, respectively). The proximal selectivity were better at a reaction temperature of $50{ }^{\circ} \mathrm{C}$ than at reflux temperature for $\mathrm{p}$ $\mathbf{1 C l}, \mathrm{p}-\mathbf{3 C l}$, and p-4Cl. The synthetic yields for p-1Cl, p-3Cl, and p-4Cl were poor because of unreacted bidentate ligands and $\mathrm{Ru}($ tpy $) \mathrm{Cl}_{3}$. The reaction of $6^{\prime}$-substituted pyqu, i.e., 2-[2'-(6'chloro)pyridyl]quinoline, and $\mathrm{Ru}(\mathrm{tpy}) \mathrm{Cl}_{3}$ was much slower than those of the other derivatives because of the sterically bulky bidentate ligand. A mild reaction of $\mathrm{Ru}(\mathrm{tpy}) \mathrm{Cl}_{3}$ with $6^{\prime}$ substituted pyqu at $50{ }^{\circ} \mathrm{C}$ gave no product even after 3 days. At reflux temperature, $23 \%$ of the product was obtained after $24 \mathrm{~h}$; the proximal isomer was the main product. We tried to increase the synthetic yield by performing the reaction under high pressure and at high temperature ( $1 \mathrm{MPa}$ and $150{ }^{\circ} \mathrm{C}$ ), but $\mathrm{Ru}(\text { tpy })_{2}$ was obtained as the main product. In contrast to the proximal selectivity of thermal reactions with $\mathrm{Ru}(\mathrm{tpy}) \mathrm{Cl}_{3}$ and pyqu derivatives observed in this work, it has been reported that the thermal reactions of $\mathrm{Ru}(\mathrm{tpy}) \mathrm{Cl}_{3}$ and 2-(2-pyridyl)-1,8-naphthyridine ${ }^{\mathbf{1 1 b}, \mathbf{1 1 d}}$ or phenanthroline derivatives ${ }^{\mathbf{1 6}}$ with a pendant moiety at the 2-position are distal selective. We previously reported that the $\mathrm{d}-\mathbf{1 H}_{\mathbf{2}} \mathrm{O}$ would be more instable rather than the p-1 $\mathbf{H}_{2} \mathrm{O}$ due steric repulsion between the pendant moiety of the pyqu ligand and a monodentate ligand as shown by the solidstate structure. The proximal selectivity of ruthenium-chloro complexes in this work could be caused by the similar reasons.

Ruthenium aqua complexes $\left(\mathrm{p}-\boldsymbol{n} \mathbf{H}_{\mathbf{2}} \mathbf{O}\right)$ were quantitatively obtained by dissolving the corresponding ruthenium chloro complexes in water. On dissolution, the purple solid ruthenium chloro complexes immediately changed to reddish aqueous solutions of aqua complexes. ${ }^{1} \mathrm{H}$ NMR spectra of pure proximalruthenium aqua complexes were obtained immediately after dissolution. The results coincide with our previous result that the aquation of $\mathrm{p}-\mathbf{1 C l}$ proceeded at $9.2 \times 10^{-2} \mathrm{~s}^{-1}$ at room temperature, ${ }^{12}$ which is much faster the aquation of ruthenium chloro complexes. The acceleration of the aquation reaction of p- $\boldsymbol{n C l}(n=1-4)$ is caused by steric repulsion between the monodentate chloro ligand and the pendant moiety of the bidentate ligand, as shown by the crystal structure (vide infra). 


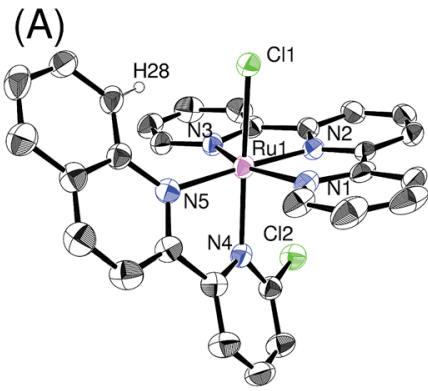

(B)

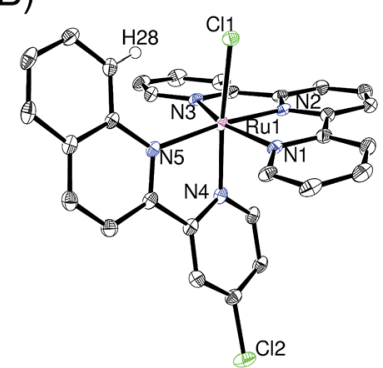

(E)

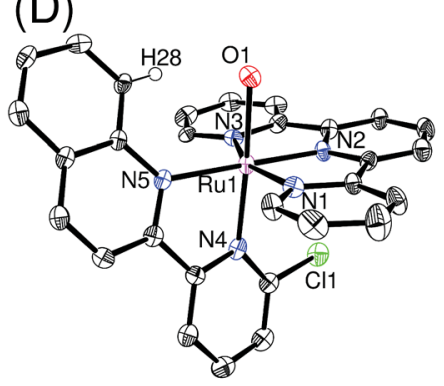

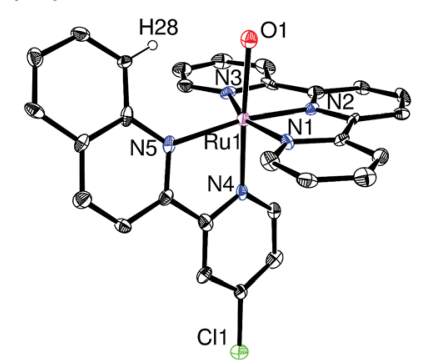

(C)

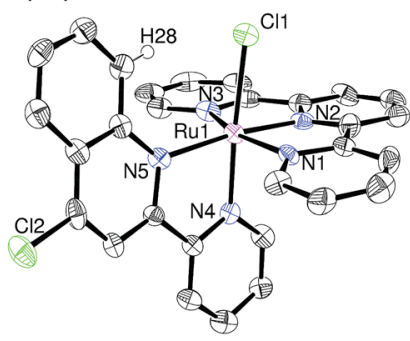

(F)

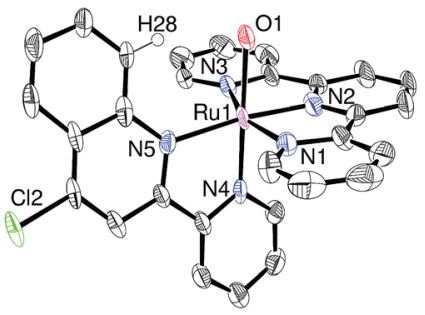

Fig. 1 ORTEP views of (A) p-[2Cl] $\left(\mathrm{PF}_{6}\right),(\mathrm{B}) \mathrm{p}-[3 \mathrm{Cl}]\left(\mathrm{BF}_{4}\right),(\mathrm{C}) \mathrm{p}-[4 \mathrm{Cl}]\left(\mathrm{PF}_{6}\right) \cdot \mathrm{EtOH},(\mathrm{D}) \mathrm{p}-\left[2 \mathrm{H}_{2} \mathrm{O}\right]\left(\mathrm{PF}_{6}\right)_{2} \cdot 2 \mathrm{H}_{2} \mathrm{O},(\mathrm{E}) \mathrm{p}-\left[3 \mathrm{H}_{2} \mathrm{O}\right]\left(\mathrm{CF}_{3} \mathrm{SO}\right)_{2} \cdot \mathrm{H}_{2} \mathrm{O}, \mathrm{and}(\mathrm{F}) \mathrm{p}-$ $\left[4 \mathrm{H}_{2} \mathrm{O}\right]\left(\mathrm{NO}_{3}\right)_{2} \cdot 2 \mathrm{H}_{2} \mathrm{O}$. Counter anions and solvents are omitted for clarity. The ORTEP view of p-[2Cl] $(\mathrm{PF} 6)$ is plotted in $30 \%$ probability (measured at $296 \mathrm{~K}$ ), and others are plotted in $50 \%$ probability (measured at $100 \mathrm{~K}$ ).

Acceleration of ligand exchange reactions by the steric repulsion has been discussed by Takeuchi et al. ${ }^{17}$ and Bonnet et al. ${ }^{18}$ bidentate ligand, as shown by the crystal structure (vide infra).

\section{Crystal structures}

Single crystals of ruthenium chloro complexes suitable for X-ray crystallography were obtained by slow evaporation of ethanol solutions of p- $\boldsymbol{n} \mathbf{C l}$ containing counter anions $\left(\mathrm{NH}_{4} \mathrm{PF}_{6}\right.$ or $\mathrm{NaBF}_{4}$ ). Crystals of ruthenium aqua complexes were obtained by dissolving the corresponding chloro complexes in water, mixing with an ethanol solution of the counter anion and acetone, and then allowing the acetone to evaporate. Fig. 1 shows ORTEP views of the isolated complexes. The X-ray crystallographic data, and selected bond lengths and bond angles are summarized in Tables S1, $\dagger$ 1, and 2, respectively. For the ruthenium chloro complexes $\mathrm{p}-\mathbf{1 C l}, \mathbf{3} \mathbf{C l}, \mathbf{4} \mathbf{C l}$, the bond lengths and angles around the ruthenium center are similar to those reported by Reedijk et al. ${ }^{19}$ for $\left[\mathrm{Ru}\left(\text { tpy) }\left(2,2^{\prime} \text {-biquinoline }\right) \mathrm{Cl}\right]^{+}\right.$rather than those of derivatives of $\left[\mathrm{Ru}(\mathrm{tpy})\left(2,2^{\prime}\right.\right.$-bipyridine $) \mathrm{Cl}^{+}{ }^{+}{ }^{20}$ This similarity arises because of steric repulsion between a chloro ligand and pendant moieties of pyqu derivatives; this is confirmed by the distances between H28 and Cl1 (2.42-2.57 $⿱$ A). The bond length between Ru1 and N4 [2.076(4) $\mathrm{A}]$ and the N2-Ru1-N4 angle [100.58(18)] in p-2Cl are larger than those in the other complexes, by $c a .0 .05 \AA$ and $5^{\circ}$, respectively (Table 1 ). This large difference mainly arises from steric repulsion between the chloro substituent at the $6^{\prime}$-position of the pyqu ligand and the terpyridine ligand. These large differences were also observed for the ruthenium aqua complexes. The N2-Ru1-N4 angles in $\mathrm{p}$ $\mathbf{1} \mathbf{H}_{2} \mathbf{O}, 3 \mathbf{H}_{2} \mathbf{O}$, and $\mathbf{4} \mathbf{H}_{2} \mathbf{O}\left(93.6^{\circ}\right.$ to $\left.95.6^{\circ}\right)$ were similar to one another, whereas that for $\mathrm{p}-\mathbf{1 H}_{\mathbf{2}} \mathbf{O}\left[101.93(15)^{\circ}\right]$ was larger than those in the others, as shown in Table 2.

\section{Absorption spectra}

The absorption spectra of the series of ruthenium chloro and aqua complexes are shown in Fig. S8 $\dagger$ and 2, respectively. The absorption maxima and extinction coefficients in the visible

Table 1 Selected bond distances $(\AA)$ and angles $\left(^{\circ}\right)$ for series of ruthenium chloro complexes

\begin{tabular}{lrccr}
\hline & p-1Cl & p-2Cl & p-3Cl & \multicolumn{1}{c}{-4Cl } \\
\hline Ru1-Cl1 & $2.464(2)$ & $2.4058(15)$ & $2.4462(9)$ & $2.446(2)$ \\
Ru1-N1 & $2.087(8)$ & $2.090(5)$ & $2.092(3)$ & $2.057(7)$ \\
Ru1-N2 & $1.961(4)$ & $1.946(4)$ & $1.955(3)$ & $1.950(7)$ \\
Ru1-N3 & $2.085(8)$ & $2.063(4)$ & $2.075(3)$ & $2.072(7)$ \\
Ru1-N4 & $2.025(5)$ & $2.076(4)$ & $2.020(3)$ & $2.031(7)$ \\
Ru1-N5 & $2.138(4)$ & $2.099(5)$ & $2.115(3)$ & $2.148(6)$ \\
Cl1-Ru1-N1 & $86.16(13)$ & $86.18(12)$ & $84.93(8)$ & $91.00(19)$ \\
Cl1-Ru1-N2 & $82.39(14)$ & $83.36(13)$ & $86.14(8)$ & $80.33(19)$ \\
Cl1-Ru1-N3 & $92.01(15)$ & $90.47(12)$ & $96.03(8)$ & $87.31(19)$ \\
Cl1-Ru1-N4 & $171.94(13)$ & $170.54(13)$ & $169.14(8)$ & $176.08(18)$ \\
Cl1-Ru1-N5 & $105.20(12)$ & $98.03(13)$ & $101.12(8)$ & $105.82(19)$ \\
N1-Ru1-N2 & $79.68(18)$ & $79.8(2)$ & $79.50(11)$ & $80.0(3)$ \\
N1-Ru1-N3 & $160.20(17)$ & $159.7(2)$ & $159.02(11)$ & $160.3(3)$ \\
N1-Ru1-N4 & $85.95(18)$ & $86.08(17)$ & $84.65(11)$ & $87.6(3)$ \\
N1-Ru1-N5 & $101.48(17)$ & $96.50(19)$ & $99.99(11)$ & $95.5(2)$ \\
N2-Ru1-N3 & $80.53(18)$ & $79.94(19)$ & $79.66(11)$ & $80.4(3)$ \\
N2-Ru1-N4 & $94.51(19)$ & $100.58(18)$ & $94.96(11)$ & $95.8(3)$ \\
N2-Ru1-N5 & $172.36(18)$ & $175.98(18)$ & $172.67(11)$ & $172.5(3)$ \\
N3-Ru1-N4 & $94.83(19)$ & $98.66(17)$ & $94.80(11)$ & $92.7(3)$ \\
N3-Ru1-N5 & $98.03(17)$ & $103.79(18)$ & $100.37(11)$ & $103.9(3)$ \\
N4-Ru1-N5 & $78.09(18)$ & $77.48(18)$ & $77.71(11)$ & $78.0(2)$ \\
& & & &
\end{tabular}


Table 2 Selected bond distances $(\AA)$ and angles $\left({ }^{\circ}\right)$ for series of ruthenium aqua complexes

\begin{tabular}{|c|c|c|c|c|}
\hline & $\mathrm{p}-\mathbf{- 1} \mathbf{H}_{2} \mathbf{O}$ & $\mathrm{p}-2 \mathbf{H}_{2} \mathbf{O}$ & $\mathrm{p}-3 \mathbf{H}_{2} \mathbf{O}$ & $\mathrm{p}-4 \mathrm{H}_{2} \mathrm{O}$ \\
\hline Ru1-O1 & $2.137(8)$ & $2.129(4)$ & $2.157(6)$ & $2.136(5)$ \\
\hline Ru1-N1 & $2.061(8)$ & $2.091(4)$ & $2.081(8)$ & $2.054(6)$ \\
\hline Ru1-N2 & $1.937(7)$ & $1.961(3)$ & $1.949(8)$ & $1.952(6)$ \\
\hline Ru1-N3 & $2.060(8)$ & $2.070(4)$ & $2.068(8)$ & $2.066(6)$ \\
\hline Ru1-N4 & $2.091(9)$ & $2.057(4)$ & $2.030(8)$ & $2.002(6)$ \\
\hline Ru1-N5 & $2.139(9)$ & $2.096(3)$ & $2.146(8)$ & $2.086(5)$ \\
\hline O1-Ru1-N1 & $86.9(3)$ & $87.51(15)$ & $88.2(3)$ & $88.5(2)$ \\
\hline O1-Ru1-N2 & $84.0(3)$ & $84.44(14)$ & $84.4(3)$ & $85.1(2)$ \\
\hline O1-Ru1-N3 & $91.0(3)$ & $89.52(15)$ & $88.1(3)$ & $88.0(2)$ \\
\hline O1-Ru1-N4 & $175.5(3)$ & $170.76(14)$ & 177.1(3) & $177.3(2)$ \\
\hline O1-Ru1-N5 & 105.1(3) & $95.33(14)$ & $103.9(3)$ & 101.1(2) \\
\hline N1-Ru1-N2 & $79.7(3)$ & $79.53(15)$ & $79.3(3)$ & $79.9(2)$ \\
\hline N1-Ru1-N3 & $159.5(3)$ & $158.81(13)$ & $160.1(3)$ & $159.7(2)$ \\
\hline N1-Ru1-N4 & $88.6(3)$ & $87.09(16)$ & 89.4(3) & $89.0(2)$ \\
\hline N1-Ru1-N5 & $101.3(3)$ & $98.12(15)$ & $96.5(3)$ & $96.8(2)$ \\
\hline N2-Ru1-N3 & $79.9(3)$ & $79.31(15)$ & $80.9(3)$ & $79.9(2)$ \\
\hline N2-Ru1-N4 & $94.4(3)$ & 101.93(15) & $93.6(3)$ & $95.6(2)$ \\
\hline N2-Ru1-N5 & $170.8(3)$ & $177.64(17)$ & $170.7(3)$ & $172.9(2)$ \\
\hline N3-Ru1-N4 & $92.9(3)$ & $98.20(16)$ & $93.7(3)$ & $94.7(2)$ \\
\hline N3-Ru1-N5 & $98.9(3)$ & $103.04(14)$ & $103.4(3)$ & $103.5(2)$ \\
\hline N4-Ru1-N5 & 76.6(4) & $78.03(14)$ & $78.0(3)$ & 78.1(2) \\
\hline
\end{tabular}

region are summarized in Table 3. All the complexes showed $\pi-$ $\pi^{*}$ transitions in the UV region and MLCT transitions in the visible region. As expected from the ligand field strengths of the chloro and aqua ligands, the absorption maxima of the MLCT transitions for the ruthenium chloro complexes (p- $\boldsymbol{n} \mathbf{C l})$ were red-shifted from those of the corresponding ruthenium aqua complexes (p- $\boldsymbol{n} \mathbf{H}_{\mathbf{2}} \mathbf{O}$ ) by $20-37 \mathrm{~nm}$. The MLCT absorption bands of p-3 $\mathbf{H}_{2} \mathrm{O}$ and p- $4 \mathrm{H}_{2} \mathrm{O}\left(\lambda_{\max }=507 \mathrm{~nm}\right)$ were red shifted by $5 \mathrm{~nm}$ compared with that of $\mathrm{p}-\mathbf{1} \mathbf{H}_{2} \mathrm{O}\left(\lambda_{\max }=502 \mathrm{~nm}\right)$. The $\mathrm{p}-\mathbf{2} \mathbf{H}_{\mathbf{2}} \mathrm{O}$ complex $\left(\lambda_{\max }=515 \mathrm{~nm}\right)$ showed the largest red shift among the series of aqua complexes (Fig. 2). The red shifts in the spectra can be explained by stabilization of the $\pi^{*}$ levels of the pyqu ligands by the chloro substituent, according to density functional theory (DFT) calculations (vide infra).

\section{Photoisomerization}

The reversible photoisomerizations of the series of ruthenium aqua complexes were investigated using ${ }^{1} \mathrm{H}$ NMR spectroscopy. UV-vis absorption spectra of the complexes

Table 3 Summary of absorption properties and parameters for reversible photoisomerization

\begin{tabular}{|c|c|c|c|}
\hline & & & Photoisomerization \\
\hline & $\lambda_{\max } / \mathrm{nm}\left(\varepsilon / \mathbf{M}^{-1} \mathrm{~cm}^{-1}\right)$ & $K_{\mathrm{pi}}$ & $\Phi_{\mathrm{p} \rightarrow \mathrm{d}}, \Phi_{\mathrm{d} \rightarrow \mathrm{p}}$ \\
\hline $\mathrm{p}-\mathbf{1 C l}$ & $528(8700)$ & - & - \\
\hline $\mathrm{p}-2 \mathrm{Cl}$ & $552(10300)$ & - & - \\
\hline $\mathrm{p}-3 \mathrm{Cl}$ & $538(10600)$ & - & - \\
\hline $\mathrm{p}-4 \mathrm{Cl}$ & $537(11900)$ & - & - \\
\hline $\mathrm{p}-1 \mathrm{H}_{2} \mathrm{O}$ & $502(8800)$ & 3.2 & $8.3 \times 10^{-3}, 2.4 \times 10^{-2}$ \\
\hline $\mathrm{p}-2 \mathrm{H}_{2} \mathrm{O}$ & $515(8100)$ & 3.2 & $1.7 \times 10^{-2}, 5.7 \times 10^{-2}$ \\
\hline $\mathrm{p}-3 \mathbf{H}_{2} \mathbf{O}$ & $507(10700)$ & 3.0 & $8.2 \times 10^{-3}, 2.7 \times 10^{-2}$ \\
\hline $\mathrm{p}-4 \mathrm{H}_{2} \mathrm{O}$ & $507(12300)$ & 2.7 & $8.6 \times 10^{-3}, 2.0 \times 10^{-2}$ \\
\hline
\end{tabular}

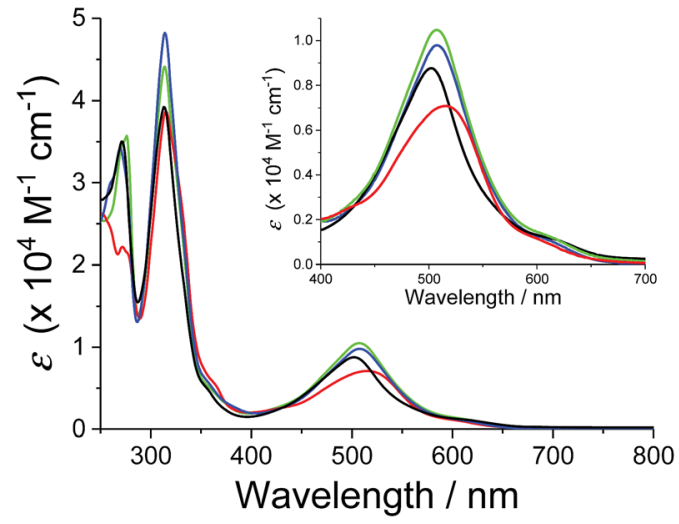

Fig. 2 Absorption spectra of $p-1 \mathrm{H}_{2} \mathrm{O}$ (black), p-2 $\mathrm{H}_{2} \mathrm{O}$ (red), $\mathrm{p}-3 \mathrm{H}_{2} \mathrm{O}$ (blue), and $\mathrm{p}-4 \mathrm{H}_{2} \mathrm{O}$ (green) in water. Absorption spectrum of $\mathrm{p}-1 \mathrm{H}_{2} \mathrm{O}$ was obtained from ref. 12

were recorded during the photochemical reactions, but the differences between the proximal and distal isomers were too small for accurate evaluation of the photoisomerization. Fig. 3 shows representative ${ }^{1} \mathrm{H}$ NMR spectroscopic changes for $\mathrm{p}-\mathbf{4} \mathbf{H}_{2} \mathbf{O}$ under visible-light irradiation $(\lambda>380 \mathrm{~nm}, 70 \mathrm{~mW}$ $\left.\mathrm{cm}^{-2}\right)$. The doublet peak at $9.17 \mathrm{ppm}$ for $\mathrm{p}-\mathbf{4} \mathrm{H}_{2} \mathrm{O}$ decreased with irradiation time and a new doublet peak from the distal isomer, $\mathrm{d}-\mathbf{4} \mathrm{H}_{2} \mathbf{O}$, appeared at $9.66 \mathrm{ppm}$; these peaks are assigned to the protons at the 8- and $6^{\prime}$-positions, respectively, of the pyqu ligand. The kinetic profiles obtained by integration of the proximal and distal isomer peaks are shown in Fig. 3(B). The kinetic profiles show that reversible photoisomerization occurred to give a mixture of p-and d$\mathbf{4 H}_{2} \mathbf{O}$ in the photostationary state. Table 3 shows the kinetic parameters for the photoisomerizations. The equilibrium constants $\left(K_{\mathrm{pi}}=\left[\mathrm{p}-\boldsymbol{n} \mathbf{H}_{2} \mathbf{O}\right] /\left[\mathrm{d}-\boldsymbol{n} \mathbf{H}_{2} \mathbf{O}\right]\right)$ in the photostationary state are close to one another. The data in Table 3 show that the quantum yields for the photoisomerization using monochromatic light at $508 \mathrm{~nm}$ (full width at half maximum $\left.=1.5 \mathrm{~nm}, 1.6 \mathrm{~mW} \mathrm{~cm}{ }^{-2}\right)$ were similar $(0.0082-0.0086)$ for $\mathrm{p}$ $\mathbf{1} \mathrm{H}_{2} \mathrm{O}, \mathbf{3} \mathrm{H}_{2} \mathrm{O}$, and $4 \mathrm{H}_{2} \mathrm{O}$. However, the quantum yield for p$2 \mathrm{H}_{2} \mathrm{O}$ was 0.017 , which is almost twice as large as those for the other aqua complexes.
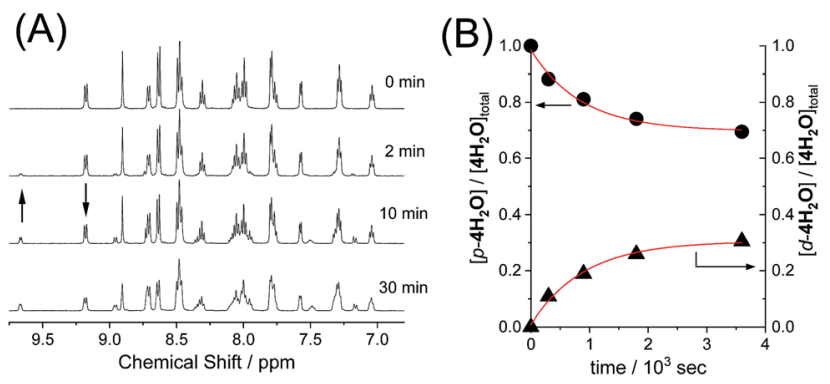

Fig. 3 (A) ${ }^{1} \mathrm{H}$ NMR spectra of $\mathrm{p}-4 \mathrm{H}_{2} \mathrm{O}(4 \mathrm{mM})$ in $\mathrm{D}_{2} \mathrm{O}$ under the light irradiation $\left(\lambda>380 \mathrm{~nm}, 70 \mathrm{~mW} \mathrm{~cm}{ }^{-2}\right)$ at $293 \mathrm{~K}$. (B) kinetic profiles of $p$ $4 \mathrm{H}_{2} \mathrm{O}(-)$ and $\mathrm{d}-4 \mathrm{H}_{2} \mathrm{O}(\Delta)$ under the light irradiation, where the ratio of proximal and distal isomers was estimated from peak areas at $9.17 \mathrm{ppm}$ and $9.66 \mathrm{ppm}$, respectively. 


\section{DFT calculations}

DFT calculations for the series of ruthenium aqua complexes were performed with the B3LYP functional and LanL2DZ basis set using the polarizable continuum model in water. The energy-optimized structures and molecular orbitals of p- $\boldsymbol{n} \mathbf{H}_{2} \mathbf{O}$ are shown in Fig. S10-S13. $\dagger$ The highest occupied molecular orbitals (HOMOs) of the complexes are mainly localized on the metal center and their levels lie in the range -6.134 to $-6.197 \mathrm{eV}$, as shown in Fig. S10-S13. $\dagger$ The lowest unoccupied molecular orbitals (LUMOs) of $\mathrm{p}-\mathbf{1 H}_{\mathbf{2}} \mathrm{O}$ are localized on both the tpy and the pyqu ligands, whereas those of $\mathrm{p}-\mathbf{2} \mathbf{H}_{2} \mathbf{O}, \mathrm{p}-\mathbf{3} \mathbf{H}_{2} \mathrm{O}$, and p-4 $\mathbf{H}_{2} \mathrm{O}$ are localized on the chloro-substituted pyqu ligands because of stabilization of their $\pi^{*}$ orbitals by the electronwithdrawing chloro substituents. The LUMO levels of the chloro-substituted complexes are more stabilized than that of $\mathrm{p}$ $\mathbf{1 H}_{\mathbf{2}} \mathrm{O}$, by 0.107 to $0.171 \mathrm{eV}$. The red shift in the absorption spectra of the chloro-substituted complexes is ascribed to stabilization of the LUMO levels, according to the timedependent DFT calculations, as shown in Fig. S14. $\dagger$ In the calculated spectra, the absorption maximum in the MLCT transition for $\mathrm{p}-\mathbf{2 H}_{2} \mathbf{O}(482 \mathrm{~nm})$ was more red-shifted than those

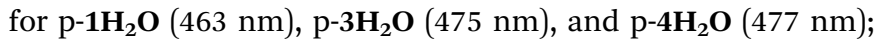
this shows good agreement with the experimental results in absorption spectroscopy. Fig. 4 shows the energy level diagram of the molecular orbitals (MOs) of p- $\boldsymbol{n} \mathbf{H}_{2} \mathbf{O}$. The MO levels of p$\mathbf{3} \mathbf{H}_{2} \mathrm{O}$ and $\mathrm{p}-\mathbf{4} \mathbf{H}_{2} \mathrm{O}$ are almost identical. The energies of the metal-centered unoccupied orbitals $\left(\mathrm{d} \sigma^{*}\right.$, shown in red in Fig. 4) for p-1 $\mathbf{H}_{2} \mathbf{O}, \mathrm{p}-\mathbf{3} \mathbf{H}_{2} \mathrm{O}$, and $\mathrm{p}-\mathbf{4} \mathbf{H}_{2} \mathrm{O}$ are $-0.794,-0.841$, and $-0.833 \mathrm{eV}$, respectively, indicating that the MC levels among the three complexes are almost identical. The energy level of the $\mathrm{d} \sigma^{*}$ orbital (LUMO+7) for $\mathrm{p}-\mathbf{2} \mathbf{H}_{\mathbf{2}} \mathbf{O}(-1.132 \mathrm{eV}$ ) is more stabilized than those of the other isomers by $0.195-0.338 \mathrm{eV}$. This indicates that the steric repulsion between the tridentate ligand and the chloro substituent of the pyqu ligand in $\mathbf{p}-2 \mathbf{H}_{2} \mathbf{O}$ weakens the ligand field. It should be noted that stabilization of $\mathrm{d} \sigma^{*}$ by steric repulsion occurs in the distal isomers. The energy level of the $\mathrm{d} \sigma^{*}$ orbital for $\mathrm{p}-\mathbf{2} \mathbf{H}_{2} \mathbf{O}(-0.99 \mathrm{eV})$ is lower than those for the other derivatives by $0.07-0.13 \mathrm{eV}$ (see Fig. $\mathrm{S} 15 \dagger$ ). Several groups

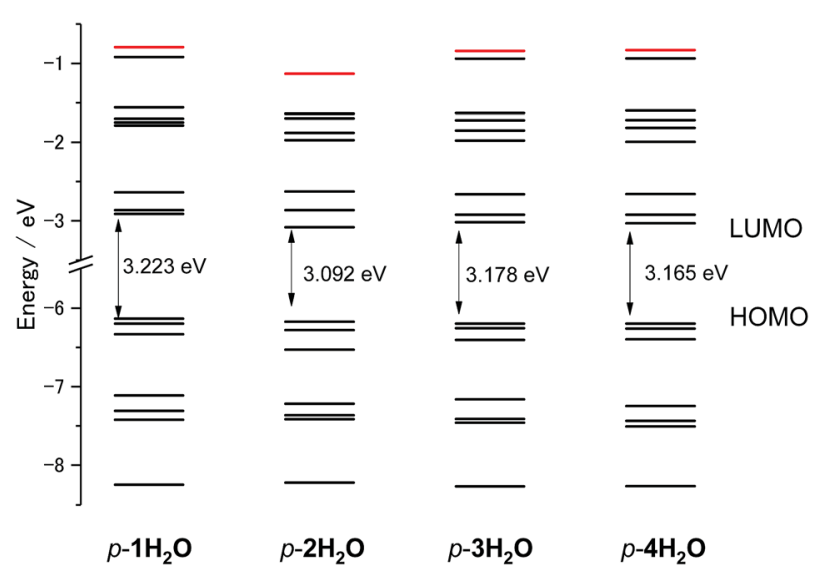

Fig. 4 Energy level diagram of molecular orbitals of $\mathrm{p}-\mathrm{nH}_{2} \mathrm{O}(n=1-4)$. The energy level of Ru-N antibonding $d \sigma^{*}$ orbitals (LUMO+8 for $p$ $1 \mathrm{H}_{2} \mathrm{O}, 3 \mathrm{H}_{2} \mathrm{O}$, and $4 \mathrm{H}_{2} \mathrm{O}$, and LUMO+7 for $\mathrm{p}-2 \mathrm{H}_{2} \mathrm{O}$ ) are marked in red. have reported rate enhancement by steric effects in photosubstitution reactions of ruthenium(II) complexes. ${ }^{4 f, 6}$ Our calculation results support the suggestion that steric hindrance accelerates the photoisomerization of ruthenium aqua complexes, including the photodissociation of an aqua ligand.

\section{Thermal isomerization}

Thermal isomerizations of the series of ruthenium aqua complexes were examined by variable temperature (VT) NMR spectroscopy. The proximal isomer was irradiated in room temperature to reach photostationary state prior to the measurement. The mixtures of proximal and distal isomers were heated at $323 \mathrm{~K}$ overnight in the dark. Under the conditions used, proximal/distal ratio for $\mathbf{1 H}_{2} \mathrm{O}, \mathbf{3} \mathbf{H}_{2} \mathbf{O}$, and $4 \mathbf{H}_{2} \mathrm{O}$ were unchanged. In contrast, during heating of the mixture of $\mathrm{p}$ $2 \mathbf{H}_{2} \mathrm{O}$ and $\mathrm{d}-\mathbf{2} \mathbf{H}_{2} \mathrm{O}$, the proportion of the proximal isomer increased from 0.76 to 0.86 . We repeated the cycle of light irradiation at room temperature and incubation in the dark at $323 \mathrm{~K}$. The changes in the proportion of $\mathrm{p}-\mathbf{2 H}_{2} \mathrm{O}$ are shown in Fig. 5. The proportion of $\mathrm{p}-\mathbf{2} \mathbf{H}_{2} \mathrm{O}$ increased during incubation in the dark and decreased under light irradiation. The proportion of the proximal isomer did not change when the sample was left at room temperature in the dark for several months. We consider that thermal isomerization of $\mathbf{2 H}_{2} \mathbf{O}$ occurs because of steric hindrance around the metal center. As shown in the crystal structures of the ruthenium aqua complex, the enhanced steric repulsion between tridentate and bidentate ligands in the p-2 $\mathbf{H}_{2} \mathbf{O}$ by $6^{\prime}$-substituted chloro ligand leads to the distortion from octahedral geometry. The enhancement of thermal isomerization by distortion around the metal center has been reported for a ruthenium alloxazine complex by Kojima et al. ${ }^{7 a}$ and for a ruthenium complex with a 1,10-phenanthroline ligand with bulky moieties. ${ }^{21}$ We thus assume that decrease of ligand field in $\mathrm{p}-\mathbf{2 H}_{2} \mathrm{O}$ assists the bond dissociation of $\mathrm{Ru}$-oxygen bond upon heating to give five-coordinated intermediates, followed by formation of the isomerized complexes.

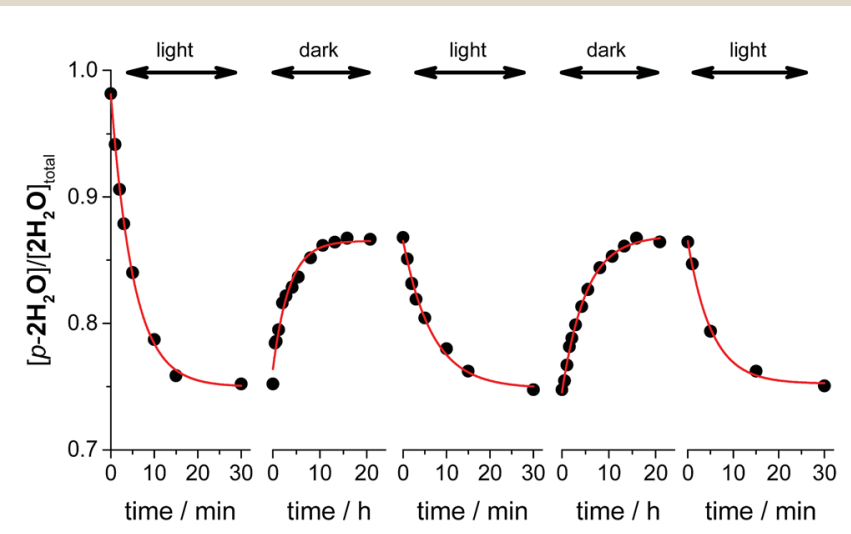

Fig. 5 Kinetic profiles of proximal- $2 \mathrm{H}_{2} \mathrm{O}$ (total concentration, $\left[2 \mathrm{H}_{2}-\right.$ $\mathrm{O}_{\text {total }}=2.7 \mathrm{mM}$ ) in the repeated cycles of photoisomerization and thermal isomerization. The ratios of the proximal isomer were calculated from the peak integration of the proximal isomer at $8.72 \mathrm{ppm}(1 \mathrm{H})$ and the distal isomer at $8.15 \mathrm{ppm}(4 \mathrm{H})$. Conditions: light source $\lambda>$ $380 \mathrm{~nm}, T=293 \mathrm{~K}$ under the light irradiation, $T=323 \mathrm{~K}$ in the dark reaction, solvent $\mathrm{D}_{2} \mathrm{O}$. 


\section{Conclusion}

In the present study, we demonstrated photoisomerization and thermal isomerization of a series of ruthenium aqua complexes with asymmetric bidentate ligands. The introduction of an electron-withdrawing chloro moiety at the 4 - and $4^{\prime}$-positions of the pyqu ligand affected the absorption properties of the complexes ( $\mathrm{p}-\mathbf{3} \mathbf{H}_{2} \mathbf{O}$ and $\mathbf{4} \mathbf{H}_{2} \mathbf{O}$ ). Their proximal-distal photoisomerization reactions were similar and no thermal isomerization was observed. In contrast, the sterically hindered complex with a $6^{\prime}$-substituted pyqu ligand gave a high photoisomerization quantum yield and showed thermal back isomerization. These results will contribute to the design of photoresponsive molecules and molecular catalysts utilized under the light irradiation.

\section{Experimental section}

\section{Materials}

$\mathrm{Ru}($ tpy $) \mathrm{Cl}_{3},{ }^{22} 2$-(2'-pyridyl)quinoline $N$-oxide, ${ }^{15} 2$-[2'-(6'-chloro)pyridyl $]$ quinoline, ${ }^{15}$ 2-[2'-(4'-chloro)pyridyl $]$ quinoline, ${ }^{15}$ p-1Cl, ${ }^{12}$ and $\mathrm{p}-\mathbf{1} \mathbf{H}_{2} \mathbf{O}^{\mathbf{1 2}}$ were prepared as previously described. Silica-gel column chromatography was performed using silica gel 60 (Kanto Chemical Co., Inc., 100-210 $\mu \mathrm{m}$ ). The metal complexes were purified using Sephadex LH-20 (GE Healthcare). All other reagents were purchased, and used without further purification.

\section{Measurements and DFT calculations}

${ }^{1} \mathrm{H}$ NMR spectra were recorded using a Bruker $500 \mathrm{MHz}$ spectrometer. ${ }^{1} \mathrm{H}$ NMR spectra were referenced using tetramethylsilane in organic solvents or sodium 3-(trimethylsilyl) propionate-2,2,3,3- $d_{4}$ in $\mathrm{D}_{2} \mathrm{O}$ as an internal standard. X-ray diffraction data were recorded using a Bruker SMART APEXII CCD area detector diffractometer; the detector was positioned at a distance of $6.0 \mathrm{~cm}$ from the crystal and monochromated Mo $\mathrm{K} \alpha$ radiation $(\lambda=0.71073 \AA)$ from a rotating anode with a mirror focusing apparatus operated at $1.2 \mathrm{~kW}(50 \mathrm{kV}, 24 \mathrm{~mA})$ was used. A sample crystal was mounted on a glass fiber for X-ray diffraction measurements. The structures were solved by direct methods and expanded using Fourier techniques. The non-hydrogen atoms were refined anisotropically. Hydrogen atoms were included but not refined. The final cycle of fullmatrix least-squares refinement was based on the observed reflections $[I>2.00 \sigma(I)]$ and variable parameters, and converged with unweighted and weighted agreement factors $R$ and $R_{\mathrm{w}}$. UVvis absorption spectra were recorded using a Hitachi U-3310 UVvis spectrometer and a quartz cell with a light pass length of $1 \mathrm{~cm}$. DFT calculations were performed using the Gaussian 09 package of programs. ${ }^{23}$ Molecular structures were fully optimized using the B3LYP method, which uses the hybrid Becke's three-parameter exchange functional ${ }^{24}$ with the correlation energy functional of Lee, Yang, and Parr. ${ }^{25}$ Calculations were performed using the standard double- $\zeta$-type LanL2DZ basis set implemented in Gaussian 09.

The internal quantum yields $\left(\Phi_{\text {proximal } \rightarrow \text { distal }}\right)$ for photoisomerization were obtained from integrations of the resonances for p- $\boldsymbol{n} \mathbf{H}_{2} \mathrm{O}$ and distal- $\boldsymbol{n} \mathbf{H}_{2} \mathbf{O}$ in the ${ }^{1} \mathrm{H}$ NMR spectra under light irradiation. Monochromic light (508.4 nm, full width at half maximum $=1.5 \mathrm{~nm}, 1.6 \mathrm{~mW} \mathrm{~cm}{ }^{-2}$ ) passed through a band pass filter (Spectro-Film Inc.) was used. The internal quantum yields were calculated according to the following equation:

$$
\Phi_{\text {proximal } \rightarrow \text { distal }}=\frac{h c N_{\mathrm{A}} k n_{\text {int }}}{p \lambda A(1-T)}
$$

where $k, n_{\text {int }}, h, p, \lambda, c, N_{\mathrm{A}}, T$, and $A$ are the rate constant for photoisomerization ( $\mathrm{p}-\boldsymbol{n} \mathbf{H}_{\mathbf{2}} \mathbf{O}$ to d- $\left.\boldsymbol{n} \mathbf{H}_{\mathbf{2}} \mathbf{O}\right)$, initial amount $\left(n_{\mathrm{int}}=\right.$ $2 \mu \mathrm{mol})$ of $\mathrm{p}-\boldsymbol{n} \mathbf{H}_{2} \mathbf{O}$, Plank's constant, photon flux $(p=1.6 \mathrm{~mW}$ $\left.\mathrm{cm}^{-2}\right)$, wavelength $\left(\lambda=5.084 \times 10^{-7} \mathrm{~m}\right)$, the speed of light, Avogadro's number, transmittance, and irradiated area $(A=1.2$ $\mathrm{cm}^{2}$ ), respectively. The internal quantum yield for the back reaction $\left(\Phi_{\text {distal } \rightarrow \text { proximal }}\right)$ was calculated according to the following equation: ${ }^{15}$

$$
\Phi_{\text {distal } \rightarrow \text { proximal }}=\frac{\left[\text { proximal }-\boldsymbol{n} \mathbf{H}_{2} \mathbf{O}\right]_{\infty}}{\left[\text { distal- } \boldsymbol{n} \mathbf{H}_{2} \mathbf{O}\right]_{\infty}} \Phi_{\text {proximal } \rightarrow \text { distal }}
$$

where [proximal- $\left.\boldsymbol{n} \mathbf{H}_{2} \mathbf{O}\right]_{\infty}$ and $\left[\text { distal- } \boldsymbol{n} \mathbf{H}_{2} \mathbf{O}\right]_{\infty}$ are the concentrations of p-n $\mathbf{H}_{2} \mathbf{O}$ and d- $\boldsymbol{n} \mathbf{H}_{2} \mathrm{O}$ at the photochemical steady state.

\section{Syntheses}

2-(2'-Pyridyl)-4-chloroquinoline. 2-(2'-Pyridyl)quinoline $\mathrm{N}$ oxide (272 mg, $1.22 \mathrm{mmol}$ ) was dissolved in $\mathrm{POCl}_{3}(3 \mathrm{~mL})$ and the solution was refluxed under nitrogen for $3 \mathrm{~h}$. The reaction mixture was slowly added to an aqueous solution of $\mathrm{Na}_{2} \mathrm{CO}_{3}$. After cooling to room temperature, the suspension was extracted with $\mathrm{CHCl}_{3}(30 \mathrm{~mL} \times 2)$. The organic layer was dried with $\mathrm{MgSO}_{4}$ and evaporated to dryness. The crude product (123 mg) was purified with silica gel chromatography using a mixed solvent $\left(\mathrm{CHCl}_{3}\right.$ : AcOEt : hexane $\left.=50: 15: 135, \mathrm{v} / \mathrm{v} / \mathrm{v}\right)$. The first band was collected and evaporated to dryness. Yield $94 \mathrm{mg}$ (32\%). Anal. calcd for 2-(2'-pyridyl)-4-chloroquinoline, $\mathrm{C}_{14} \mathrm{H}_{9} \mathrm{ClN}_{2}$ : C, 69.86; H, 3.77; N, 11.64. Found: C, 69.88; H, 3.62, N, 11.28. ${ }^{1} \mathrm{H}$ NMR (500.13 $\left.\mathrm{MHz}, \mathrm{CDCl}_{3}\right) \delta \mathrm{ppm} 8.75(\mathrm{~d}, J=$ $\left.4.7 \mathrm{~Hz}, 1 \mathrm{H}, H_{6^{\prime}}\right), 8.71\left(\mathrm{~s}, 1 \mathrm{H}, H_{3}\right), 8.66\left(\mathrm{~d}, J=8.0 \mathrm{~Hz}, 1 \mathrm{H}, H_{3^{\prime}}\right)$, $8.28(\mathrm{~d}, J=8.3 \mathrm{~Hz}, 1 \mathrm{H}), 8.20(\mathrm{~d}, J=8.4 \mathrm{~Hz}, 1 \mathrm{H}), 7.89(\mathrm{dt}, J=7.8$, $1.7 \mathrm{~Hz}, 1 \mathrm{H}), 7.80(\mathrm{t}, J=7.1 \mathrm{~Hz}, 1 \mathrm{H}), 7.66(\mathrm{t}, J=7.6 \mathrm{~Hz}, 1 \mathrm{H}), 7.39$ (dd, $J=7.4,4.8 \mathrm{~Hz}, 1 \mathrm{H}) .{ }^{13} \mathrm{C}$ NMR $\left(125.77 \mathrm{MHz}, \mathrm{CDCl}_{3}\right) \delta \mathrm{ppm}$ 156.1 , 155.3, 149.2, 148.7, 143.4, 137.1, 130.4, 130.2, 127.7, 126.4, 124.5, 124.2, 121.9, 119.2.

Proximal-[Ru(tpy)(6'-Clpyqu)Cl]Cl (p-[2Cl]Cl). To a $50 \mathrm{~mL}$ round bottom flask, $\mathrm{Ru}(\mathrm{tpy}) \mathrm{Cl}_{3}(45.4 \mathrm{mg}, 0.10 \mathrm{mmol}), 2-\left(2^{\prime}-\left(6^{\prime}-\right.\right.$ chloro)-pyridyl)quinoline $(21.3 \mathrm{mg}, 0.089 \mathrm{mmol})$, triethylamine (0.1 mL), EtOH (12 mL), water $(4 \mathrm{~mL})$, and $\mathrm{LiCl}(100 \mathrm{mg})$ were added and the mixture was refluxed for $24 \mathrm{~h}$. The purple solution was filtered through Celite in order to remove unreacted $\mathrm{Ru}($ tpy $) \mathrm{Cl}_{3}$. The filtrate was evaporated to $c a .3 \mathrm{~mL}$ and left in a refrigerator overnight. The purple precipitate was filtered and washed with ether. The precipitate was dissolved in methanol and then filtered, and the filtrate was evaporated to dryness. The crude product was purified with Sephadex LH-20 $(1.5 \mathrm{~cm} \times 20$ $\mathrm{cm})$ using methanol as an eluent. The purple band was collected 
and purity of the product was checked by TLC (eluent - saturated methanol solution of $\mathrm{NaCl}$ ). Yield $15.1 \mathrm{mg}$ (23\%). Anal. calcd for $\mathrm{p}$-[2Cl] Cl $\cdot 5 \mathrm{H}_{2} \mathrm{O}, \mathrm{C}_{29} \mathrm{H}_{20} \mathrm{Cl}_{3} \mathrm{~N}_{5} \mathrm{Ru} \cdot 5 \mathrm{H}_{2} \mathrm{O}: \mathrm{C}, 47.33 ; \mathrm{H}$, 4.11; N, 9.52. Found: C, 47.20; H, 3.97, N, 9.30. UV-vis: $\lambda$, nm $(\varepsilon$, $10^{3} \mathrm{~mol}^{-1} \mathrm{~L} \mathrm{~cm}^{-1}$ ) in EtOH, 241 (31.1), 260 (32.4), 280 (sh), 321 (44.5), 552 (10.3). ${ }^{1} \mathrm{H}$ NMR (500.13 $\left.\mathrm{MHz}, \mathrm{CDCl}_{3}: \mathrm{CD}_{3} \mathrm{OD}=9: 1\right)$ $\delta$ ppm 9.43-9.37 (m, $\left.1 \mathrm{H}, H_{8, \text { pyqu }}\right), 8.82(\mathrm{~d}, J=8.9 \mathrm{~Hz}, 1 \mathrm{H}$, $\left.H_{3 \text {,pyqu }}\right), 8.74-8.67\left(\mathrm{~m}, 2 \mathrm{H}, H_{3^{\prime} \text {,pyqu }}, H_{4 \text {,pyqu }}\right), 8.29(\mathrm{~d}, J=8.1 \mathrm{~Hz}$, $\left.2 \mathrm{H}, H_{3^{\prime}, \text { tpy }}, H_{5^{\prime}, \text { tpy }}\right), 8.22\left(\mathrm{~d}, J=8.0 \mathrm{~Hz}, 2 \mathrm{H}, H_{3, \text { tpy }}, H_{3^{\prime \prime} \text {,tpy }}\right), 8.14-$ $8.07\left(\mathrm{~m}, 1 \mathrm{H}, H_{5, \text { pyqu }}\right), 8.02\left(\mathrm{t}, J=8.1,8.1 \mathrm{~Hz}, 1 \mathrm{H}, H_{4^{\prime}, \text { tpy }}\right), 7.84(\mathrm{td}$, $J=7.9,1.5 \mathrm{~Hz}, 2 \mathrm{H}, H_{4, \text { tpy }}, H_{4^{\prime \prime}}$,tpy $), 7.80(\mathrm{t}, J=8.0 \mathrm{~Hz}, 1 \mathrm{H}$, $H_{4^{\prime}}$,pyqu $), 7.77-7.73\left(\mathrm{~m}, 2 \mathrm{H}, H_{6, \text { pyqu }}, H_{7, \text { pyqu }}\right), 7.71(\mathrm{~d}, J=5.5 \mathrm{~Hz}$, $2 \mathrm{H}, H_{6, \text { tpy }}, H_{6^{\prime \prime} \text {,tpy }}$ ), 7.24 (ddd, $J=7.4,5.8,1.3 \mathrm{~Hz}, 2 \mathrm{H}, H_{5, \text { tpy }}$, $H_{5^{\prime \prime}}$,tpy $), 7.04$ (dd, $J=7.9,1.0 \mathrm{~Hz}, 1 \mathrm{H}, H_{5^{\prime}}$,pyqu). ${ }^{13} \mathrm{C} \mathrm{NMR}(125.77$ $\left.\mathrm{MHz}, \mathrm{CDCl}_{3}: \mathrm{CD}_{3} \mathrm{OD}=9: 1\right) \delta \mathrm{ppm} \mathrm{161.5,} \mathrm{159.9,} \mathrm{159.6,} \mathrm{158.9,}$ $157.6,152.9,151.1,139.1,138.7,137.5$, 135.3, 131.4, 131.11, 131.09, 129.8, 129.5, 128.8, 127.5, 127.3, 124.44, 124.42, 124.39, 124.35, 123.5, 122.1, 120.1 .

Proximal-[Ru(tpy)(4'-Clpyqu)Cl]Cl, (p-[3Cl]Cl). To a $50 \mathrm{~mL}$ round bottom flask, $\mathrm{Ru}(\mathrm{tpy}) \mathrm{Cl}_{3}(90.2 \mathrm{mg}, 0.20 \mathrm{mmol}), 2-\left(2^{\prime}-\left(4^{\prime}-\right.\right.$ chloro)-pyridyl)quinoline (47.2 $\mathrm{mg}, 0.20 \mathrm{mmol}$ ), ascorbic acid (137 mg), EtOH (18 mL), water (6 mL), and LiCl (200 mg) were added and the mixture was heated at $50{ }^{\circ} \mathrm{C}$ for $6 \mathrm{~h}$. The purple solution was filtered through Celite in order to remove unreacted $\mathrm{Ru}(\mathrm{tpy}) \mathrm{Cl}_{3}$. The filtrate was evaporated to $c a .3 \mathrm{~mL}$ and left in a refrigerator overnight. The purple microcrystalline was collected by filtration and washed with an aqueous solution of $\mathrm{HCl}\left(3 \mathrm{~mol} \mathrm{~L}^{-1}, 1 \mathrm{~mL} \times 2\right)$ and ether $(3 \mathrm{~mL} \times 2)$. The crude product was dissolved in minimum amount of methanol, and then purified on Sephadex LH-20 using methanol as an eluent. The reddish purple band was collected, evaporated to $c a .3 \mathrm{~mL}$, and then left in refrigerator overnight. The purple microcrystals were collected by filtration. Yield $29.0 \mathrm{mg}(20 \%)$. Anal. calcd for $\mathrm{p}-[3 \mathrm{Cl}] \mathrm{Cl} \cdot 3.5 \mathrm{H}_{2} \mathrm{O}, \mathrm{C}_{29} \mathrm{H}_{20} \mathrm{Cl}_{3} \mathrm{~N}_{5} \mathrm{Ru} \cdot 3.5 \mathrm{H}_{2} \mathrm{O}: \mathrm{C}, 49.13 ; \mathrm{H}, 3.84 ; \mathrm{N}$, 9.88. Found: $\mathrm{C}, 49.40 ; \mathrm{H}, 3.52, \mathrm{~N}, 9.53$. UV-vis: $\lambda$, $\mathrm{nm}\left(\varepsilon, 10^{3}\right.$ $\mathrm{mol}^{-1} \mathrm{~L} \mathrm{~cm}^{-1}$ ) in EtOH, 235 (37.7), 260 (sh), 271 (38.4), 319 (49.7), 538 (10.6). ${ }^{1} \mathrm{H}$ NMR (500.13 $\left.\mathrm{MHz}, \mathrm{CDCl}_{3}: \mathrm{CD}_{3} \mathrm{OD}=9: 1\right)$ $\delta \mathrm{ppm} 10.30(\mathrm{~d}, J=8.8 \mathrm{~Hz}, 1 \mathrm{H}), 8.74(\mathrm{~d}, J=8.7 \mathrm{~Hz}, 1 \mathrm{H}), 8.60(\mathrm{~d}, J$ $=8.7 \mathrm{~Hz}, 1 \mathrm{H}), 8.54(\mathrm{~d}, J=8.1 \mathrm{~Hz}, 2 \mathrm{H}), 8.47(\mathrm{~d}, J=2.1 \mathrm{~Hz}, 1 \mathrm{H})$, $8.41(\mathrm{~d}, J=8.0 \mathrm{~Hz}, 2 \mathrm{H}), 8.24-8.15(\mathrm{~m}, 2 \mathrm{H}), 7.96$ (ddd, $J=8.6,6.9$, $1.4 \mathrm{~Hz}, 1 \mathrm{H}), 7.89$ (t, $J=7.7 \mathrm{~Hz}, 3 \mathrm{H}), 7.61$ (d, $J=5 \mathrm{~Hz}, 2 \mathrm{H}), 7.41$ $(\mathrm{d}, J=6.3 \mathrm{~Hz}, 1 \mathrm{H}), 7.26-7.19(\mathrm{~m}, 2 \mathrm{H}), 7.16(\mathrm{dd}, J=6.3,2.2 \mathrm{~Hz}$, 1H). ${ }^{13} \mathrm{C}$ NMR $\left(125.77 \mathrm{MHz}, \mathrm{CDCl}_{3}: \mathrm{CD}_{3} \mathrm{OD}=9: 1\right) \delta \mathrm{ppm}$ $160.8,158.6,158.3,155.6,152.7,152.3,151.0,143.5,138.5$, $137.4,135.7,132.1,131.2,129.8,129.7,128.4,127.3,126.6$, 125.2, 124.0, 123.0, 118.7 .

Proximal-[Ru(tpy)(4-Clpyqu)Cl]Cl (p-[4Cl]Cl). To a $50 \mathrm{~mL}$ round bottom flask, $\mathrm{Ru}(\mathrm{tpy}) \mathrm{Cl}_{3}(42.8 \mathrm{mg}, 0.097 \mathrm{mmol}), 2-\left(2^{\prime}-\right.$ pyridyl)-4-chloroquinoline $(23.3 \mathrm{mg}, 0.097 \mathrm{mmol})$, ascorbic acid (100 mg), EtOH $(9 \mathrm{~mL})$, water $(3 \mathrm{~mL})$, and $\mathrm{LiCl}(100 \mathrm{mg})$ were added and the mixture was heated at $50{ }^{\circ} \mathrm{C}$ for $4 \mathrm{~h}$. The purple solution was filtered through Celite in order to remove unreacted $\mathrm{Ru}$ (tpy) $\mathrm{Cl}_{3}$. The filtrate was evaporated to $c a .3 \mathrm{~mL}$ and left in a refrigerator overnight. The purple microcrystalline was collected by filtration and washed with an aqueous solution of $\mathrm{HCl}\left(3 \mathrm{~mol} \mathrm{~L}^{-1}, 1 \mathrm{~mL} \times 2\right)$ and ether $(3 \mathrm{~mL} \times 2)$. Yield $32.8 \mathrm{mg}(45 \%)$. Anal. calcd for $\mathrm{p}-[4 \mathrm{Cl}] \mathrm{Cl} \cdot 0.5 \mathrm{EtOH} \cdot 5 \mathrm{H}_{2} \mathrm{O}$,
$\mathrm{C}_{29} \mathrm{H}_{20} \mathrm{Cl}_{3} \mathrm{~N}_{5} \mathrm{Ru} \cdot \mathrm{CH}_{3} \mathrm{O}_{0.5} \cdot 5 \mathrm{H}_{2} \mathrm{O}: \mathrm{C}, 47.47 ; \mathrm{H}, 4.38 ; \mathrm{N}, 9.23$. Found: C, 47.58; H, 4.21, N, 8.99. UV-vis: $\lambda$, nm $\left(\varepsilon, 10^{3} \mathrm{~mol}^{-1}\right.$ $\mathrm{L} \mathrm{cm}^{-1}$ ) in EtOH, 234 (36.3), 273 (39.0), 279 (39.3), 318 (49.2), 377 (sh), 537 (11.9). ${ }^{1} \mathrm{H}$ NMR (500.13 $\mathrm{MHz}, \mathrm{CDCl}_{3}: \mathrm{CD}_{3} \mathrm{OD}=$ 9 : 1) $\delta \mathrm{ppm} 10.30(\mathrm{~d}, J=8.7 \mathrm{~Hz}, 1 \mathrm{H}), 8.65(\mathrm{~s}, 1 \mathrm{H}), 8.56-8.35(\mathrm{~m}$, $4 \mathrm{H}), 8.30(\mathrm{~d}, J=7.7 \mathrm{~Hz}, 2 \mathrm{H}), 8.11(\mathrm{t}, J=7.3,7.3 \mathrm{~Hz}, 1 \mathrm{H}), 8.02-$ $7.86(\mathrm{~m}, 2 \mathrm{H}), 7.81(\mathrm{t}, J=7.4,7.4 \mathrm{~Hz}, 1 \mathrm{H}), 7.75(\mathrm{t}, J=5.5,5.5 \mathrm{~Hz}$, $1 \mathrm{H}), 7.59(\mathrm{~d}, J=5.0 \mathrm{~Hz}, 1 \mathrm{H}), 7.37(\mathrm{~s}, 1 \mathrm{H}), 7.21-7.06(\mathrm{~m}, 3 \mathrm{H}) .{ }^{13} \mathrm{C}$ NMR (125.77 MHz, $\left.\mathrm{CDCl}_{3}: \mathrm{CD}_{3} \mathrm{OD}=9: 1\right) \delta \mathrm{ppm} 158.9,158.7$, $158.5,156.4,152.9,152.1,151.5,144.9,137.5,135.9,135.7$, $132.9,131.8,130.6,127.5,127.5,126.9,125.4,124.9,124.0$, 123.0, 119.1.

Proximal-[Ru(tpy) $\left(6^{\prime}-\mathrm{Clpyqu} \mathrm{OH}_{2}\right]\left(\mathrm{PF}_{6}\right)_{2} \quad\left(\mathrm{p}-\left[2 \mathrm{H}_{2} \mathrm{O}\right]\left(\mathrm{PF}_{6}\right)_{2}\right) \cdot \mathrm{p}-$ $[2 \mathrm{Cl}] \mathrm{Cl}(7.41 \mathrm{mg}, 10.1 \mu \mathrm{mol})$ was dissolved in water $(6 \mathrm{~mL})$ and left at room temperature for $1 \mathrm{~h}$. An aqueous solution of $\mathrm{NH}_{4} \mathrm{PF}_{6}$ was added to the solution and the precipitate was filtered and dried in vacuum. Yield $5.95 \mathrm{mg}(63 \%)$. Anal. calcd for $\mathrm{p}-\left[2 \mathbf{H}_{2}-\right.$ O] $\left(\mathrm{PF}_{6}\right)_{2} \cdot 3 \mathrm{H}_{2} \mathrm{O}, \quad \mathrm{C}_{29} \mathrm{H}_{22} \mathrm{ClF}_{12} \mathrm{~N}_{5} \mathrm{OP}_{2} \mathrm{Ru} \cdot 3 \mathrm{H}_{2} \mathrm{O}: \mathrm{C}, \quad 37.17 ; \mathrm{H}$, 3.01; N, 7.47. Found: C, 37.23; H, 3.04, N, 7.18. UV-vis of p$\left[2 \mathbf{H}_{2} \mathbf{O}\right] \mathrm{Cl}_{2}: \lambda, \mathrm{nm}\left(\varepsilon, 10^{3} \mathrm{~mol}^{-1} \mathrm{~L} \mathrm{~cm}^{-1}\right)$ in water, $232(\mathrm{sh}), 251$ (29.9), 272 (25.3), 315 (44.1), 515 (8.1) ${ }^{1} \mathrm{H}$ NMR of p- $\left[2 \mathbf{H}_{2} \mathbf{O}\right] \mathrm{Cl}_{2}$ $\left(500.13 \mathrm{MHz}, \mathrm{D}_{2} \mathrm{O}: \mathrm{CD}_{3} \mathrm{OD}=4: 1\right) \delta \mathrm{ppm} 8.90(\mathrm{~d}, J=8.8 \mathrm{~Hz}$, $1 \mathrm{H}), 8.77(\mathrm{~d}, J=8.8 \mathrm{~Hz}, 1 \mathrm{H}), 8.69-8.55(\mathrm{~m}, 4 \mathrm{H}), 8.51(\mathrm{~d}, J=$ $7.87 \mathrm{~Hz}, 2 \mathrm{H}), 8.36(\mathrm{~d}, J=8.1 \mathrm{~Hz}, 1 \mathrm{H}), 8.28(\mathrm{t}, J=8.1 \mathrm{~Hz}, 1 \mathrm{H}), 8.05$ $(\mathrm{t}, J=8.1 \mathrm{~Hz}, 2 \mathrm{H}), 7.99-7.82(\mathrm{~m}, 4 \mathrm{H}), 7.78(\mathrm{t}, J=8.1 \mathrm{~Hz}, 1 \mathrm{H}), 7.39$ $(\mathrm{t}, J=6.6 \mathrm{~Hz}, 2 \mathrm{H}), 7.22(\mathrm{~d}, J=8.1 \mathrm{~Hz}, 1 \mathrm{H}) .{ }^{13} \mathrm{C} \mathrm{NMR} \mathrm{p}-\left[2 \mathbf{H}_{2} \mathbf{O}\right] \mathrm{Cl}_{2}$ (125.77 MHz, $\left.\mathrm{D}_{2} \mathrm{O}: \mathrm{CD}_{3} \mathrm{OD}=4: 1\right) \delta \mathrm{ppm} 163.9,162.3,162.2$, $162.0,160.2$, 155.8, 152.8, 141.2, 141.1, 140.5, 139.5, 134.2, $131.9,131.72$, 131.67, 130.0, 129.7, 129.5, 126.2, 126.0, 125.3, 122.2.

Proximal-[Ru(tpy) $\left(4^{\prime}-\mathrm{Clpyqu}^{-} \mathrm{OH}_{2}\right]\left(\mathrm{PF}_{6}\right)_{2}\left(\mathrm{p}-\left[3 \mathrm{H}_{2} \mathrm{O}\right]\left(\mathrm{PF}_{6}\right)_{2}\right) \cdot \mathrm{p}$ $[3 \mathrm{Cl}] \mathrm{Cl}(8.63 \mathrm{mg}, 12.5 \mu \mathrm{mol})$ was dissolved in water $(6 \mathrm{~mL})$ and left at room temperature for $1 \mathrm{~h}$. An aqueous solution of $\mathrm{NH}_{4} \mathrm{PF}_{6}$ was added to the solution and the precipitate was filtered and dried in vacuum. Yield $7.84 \mathrm{mg}$ (76\%). Anal. calcd for $\mathrm{p}$ $\left[\mathrm{Ru}\left(\right.\right.$ tpy)(4-Clpyqu) $\left(\mu-\mathrm{O}_{2} \mathrm{H}_{3}\right) \mathrm{Ru}\left(\text { tpy)(4-Clpyqu)]( } \mathrm{PF}_{6}\right)_{3} \quad 2 \mathrm{H}_{2} \mathrm{O}, \mathrm{C}_{29^{-}}$ $\mathrm{H}_{22} \mathrm{ClF}_{12} \mathrm{~N}_{5} \mathrm{OP}_{2} \mathrm{Ru} \cdot \mathrm{H}_{2} \mathrm{O}: \mathrm{C}, 42.03 ; \mathrm{H}, 2.86 ; \mathrm{N}, 8.46$. Found: $\mathrm{C}$, 42.02; H, 2.89, N, 8.31. UV-vis of p-[3 $\left.\mathbf{H}_{2} \mathbf{O}\right] \mathrm{Cl}_{2}: \lambda, \mathrm{nm}\left(\varepsilon, 10^{3} \mathrm{~mol}^{-1}\right.$ $\mathrm{L} \mathrm{cm}^{-1}$ ) in water, 230 (37.3), 258 (sh), 270 (37.5), 314 (52.9), 508 (10.7) ${ }^{1} \mathrm{H}$ NMR of $\mathrm{p}-\left[3 \mathrm{H}_{2} \mathbf{O}\right] \mathrm{Cl}_{2}\left(500.13 \mathrm{MHz}, \mathrm{D}_{2} \mathrm{O}\right) \delta$ ppm 9.40$9.25(\mathrm{~m}, 1 \mathrm{H}), 8.83(\mathrm{~d}, J=8.7 \mathrm{~Hz}, 1 \mathrm{H}), 8.63(\mathrm{~d}, J=8.7 \mathrm{~Hz}, 1 \mathrm{H})$, 8.60-8.53 (m, 3H), $8.44(\mathrm{~d}, J=8.1 \mathrm{~Hz}, 2 \mathrm{H}), 8.34(\mathrm{dd}, J=6.4$, $3.3 \mathrm{~Hz}, 1 \mathrm{H}), 8.22(\mathrm{t}, J=8.1 \mathrm{~Hz}, 1 \mathrm{H}), 8.02-7.88(\mathrm{~m}, 4 \mathrm{H}), 7.70(\mathrm{~d}, J$ $=5.5 \mathrm{~Hz}, 2 \mathrm{H}), 7.43(\mathrm{~d}, J=6.4 \mathrm{~Hz}, 1 \mathrm{H}), 7.29-7.17(\mathrm{~m}, 2 \mathrm{H}), 7.02$ (dd, $J=6.3,1.8 \mathrm{~Hz}, 1 \mathrm{H})$.

Proximal-[Ru(tpy)(4-Clpyqu)OH $\left.\mathrm{OH}_{2}\right]\left(\mathrm{PF}_{6}\right)_{2} \quad\left(\mathbf{p}-\left[\mathbf{4 H}_{2} \mathrm{O}\right]\left(\mathrm{PF}_{6}\right)_{2}\right) . \quad \mathrm{p}-$ $[4 \mathrm{Cl}] \mathrm{Cl}(6.76 \mathrm{mg}, 8.9 \mu \mathrm{mol})$ was dissolved in water $(6 \mathrm{~mL})$ and left at room temperature for $1 \mathrm{~h}$. An aqueous solution of $\mathrm{NH}_{4} \mathrm{PF}_{6}$ was added to the solution and the precipitate was filtered and dried in vacuum. Yield $6.2 \mathrm{mg}(76 \%)$. Anal. calcd for $\mathrm{p}-\left[\mathbf{4} \mathbf{H}_{2}-\right.$ O] $\left(\mathrm{PF}_{6}\right)_{2} \cdot 2 \mathrm{H}_{2} \mathrm{O}, \quad \mathrm{C}_{29} \mathrm{H}_{22} \mathrm{ClN}_{5} \mathrm{ORuP}_{2} \mathrm{~F}_{12} \cdot 2 \mathrm{H}_{2} \mathrm{O}: \mathrm{C}, \quad 37.90 ; \mathrm{H}$, 2.85; N, 7.62. Found: C, 37.70; H, 2.88, N, 7.42. UV-vis of p$\left[4 \mathrm{H}_{2} \mathrm{O}\right] \mathrm{Cl}_{2}: \lambda, \mathrm{nm}\left(\varepsilon, 10^{3} \mathrm{~mol}^{-1} \mathrm{~L} \mathrm{~cm}^{-1}\right)$ in water, $232(\mathrm{sh}), 243$ (31.7), 260 (32.4), 276 (42.0), 314 (51.8), 507 (12.3) ${ }^{1} \mathrm{H}$ NMR of p$\left[\mathbf{4 H}_{2} \mathbf{O}\right] \mathrm{Cl}_{2}\left(500.13 \mathrm{MHz}, \mathrm{D}_{2} \mathrm{O}\right) \delta \mathrm{ppm} 9.17(\mathrm{~d}, J=8.3 \mathrm{~Hz}, 1 \mathrm{H}), 8.90$ $(\mathrm{s}, 1 \mathrm{H}), 8.70(\mathrm{~d}, J=8.3 \mathrm{~Hz}, 1 \mathrm{H}), 8.62(\mathrm{~d}, J=8.2 \mathrm{~Hz}, 2 \mathrm{H}), 8.52-$ $8.41(\mathrm{~m}, 3 \mathrm{H}), 8.31$ (t, $J=8.2,8.2 \mathrm{~Hz}, 1 \mathrm{H}), 8.11-7.90(\mathrm{~m}, 4 \mathrm{H})$, 
7.83-7.70 (m, 3H), $7.56(\mathrm{~d}, J=5.8 \mathrm{~Hz}, 1 \mathrm{H}), 7.29(\mathrm{t}, J=6.6 \mathrm{~Hz}$, $2 \mathrm{H}), 7.03(\mathrm{t}, J=6.6 \mathrm{~Hz}, 1 \mathrm{H}) .{ }^{13} \mathrm{C}$ NMR of $\mathrm{p}-\left[\mathbf{4} \mathbf{H}_{2} \mathbf{O}\right] \mathrm{Cl}_{2}(125.77$ $\left.\mathrm{MHz}, \mathrm{D}_{2} \mathrm{O}\right) \delta \mathrm{ppm} 161.7,161.3,161.2,159.4,156.0,155.1,153.5$, $146.9,141.0,139.3,138.3,135.2$, 132.6, 130.2, 129.93, 129.91, $128.5,127.9,127.7,126.6,125.8,122.2$.

\section{Conflicts of interest}

There are no conflicts to declare.

\section{Acknowledgements}

This work was supported by the JST PRESTO program, JSPS KAKENHI Grant Numbers 24107003, 24350028, 17K18433, 16K05762, and JP17M03044.

\section{References}

1 (a) S. Bonnet, B. Limburg, J. D. Meeldijk, R. J. M. K. Gebbink and J. A. Killian, J. Am. Chem. Soc., 2011, 133, 252-261; (b) B. S. Howerton, D. K. Heidary and E. C. Glazer, J. Am. Chem. Soc., 2012, 134, 8324-8327; (c) B. A. Albani, B. Peña, N. A. Leed, N. A. B. G. de Paula, C. Pavani, M. S. Baptista, K. R. Dunbar and C. Turro, J. Am. Chem. Soc., 2014, 136, 17095-17101.

2 A. Juris, V. Balzani, F. Barigelletti, S. Campagna, P. Belser and A. Von Zelewsky, Coord. Chem. Rev., 1988, 84, 85-277.

3 Y. Liu, D. B. Turner, T. N. Singh, A. M. Angeles-Boza, A. Chouai, K. R. Dunbar and C. Turro, J. Am. Chem. Soc., 2009, 131, 26-27.

4 (a) D. V. Pinnick and B. Durham, Inorg. Chem., 1984, 23, 1440-1445; (b) J. J. Rack, J. R. Winkler and H. B. Gray, J. Am. Chem. Soc., 2001, 123, 2432-2433; (c) B. Durham, J. L. Walsh, C. L. Carter and T. J. Meyer, Inorg. Chem., 1980, 19, 860-865; (d) C. R. Hecker, P. E. Fanwick and D. R. McMillin, Inorg. Chem., 1991, 30, 659-666; (e) B. A. Albani, C. B. Durr and C. Turro, J. Phys. Chem. A, 2013, 117, 13885-13892; (f) S. Bonnet, J.-P. Collin, J.-P. Sauvage and E. Schofield, Inorg. Chem., 2004, 43, 8346-8354; (g) C. E. Welby, G. K. Armitage, H. Bartley, A. Wilkinson, A. Sinopoli, B. S. Uppal, C. R. Rice and P. I. P. Elliott, Chem.-Eur. J., 2014, 20, 8467-8476; (h) P. A. Scattergood, U. Khushnood, A. Tariq, D. J. Cooke, C. R. Rice and P. I. P. Elliott, Inorg. Chem., 2016, 55, 77877796; (i) F. Weisser, S. Plebst, S. Hohloch, M. van der Meer, S. Manck, F. Führer, V. Radtke, D. Leichnitz and B. Sarkar, Inorg. Chem., 2015, 54, 4621-4635; (j) D. Unjaroen, J. B. Kasper and W. R. Browne, Dalton Trans., 2014, 43, 16974-16976; (k) D. Unjaroen, J. Chen, E. Otten and W. R. Browne, Inorg. Chem., 2017, 56, 900-907.

5 Q. Sun, S. Mosquera-Vazquez, Y. Suffren, J. Hankache, N. Amstutz, L. M. Lawson Daku, E. Vauthey and A. Hauser, Coord. Chem. Rev., 2015, 282-283, 87-99.

6 (a) J. D. Knoll, B. A. Albani, C. B. Durr and C. Turro, J. Phys. Chem. A, 2014, 118, 10603-10610; (b) D. A. Lutterman, A. A. Rachford, J. J. Rack and C. Turro, J. Phys. Chem. Lett., 2010, 1, 3371-3375.
7 (a) S. Miyazaki, T. Kojima and S. Fukuzumi, J. Am. Chem. Soc., 2008, 130, 1556-1557; (b) S. K. Padhi, R. Fukuda, M. Ehara and K. Tanaka, Inorg. Chem., 2012, 51, 5386-5392; (c) S. Bonnet, J.-P. Collin and J.-P. Sauvage, Inorg. Chem., 2006, 45, 4024-4034.

8 B. Durham, S. R. Wilson, D. J. Hodgson and T. J. Meyer, J. Am. Chem. Soc., 1980, 102, 600-607.

9 (a) A. A. Rachford and J. J. Rack, J. Am. Chem. Soc., 2006, 128, 14318-14324; (b) B. A. McClure and J. J. Rack, Angew. Chem., Int. Ed., 2009, 48, 8556-8558; (c) J. J. Rack, A. A. Rachford and A. M. Shelker, Inorg. Chem., 2003, 42, 7357-7359; (d) B. A. McClure and J. J. Rack, Inorg. Chem., 2011, 50, 75867590; (e) A. W. King, L. Wang and J. J. Rack, Acc. Chem. Res., 2015, 48, 1115-1122.

10 (a) Y. Jin, S. I. M. Paris and J. J. Rack, Adv. Mater., 2011, 23, 4312-4317; (b) Y. Jin, D. Harrington, A. A. Rachford and J. J. Rack, RSC Adv., 2014, 4, 62920-62925.

11 (a) H. Yamazaki, T. Hakamata, M. Komi and M. Yagi, J. Am. Chem. Soc., 2011, 133, 8846-8849; (b) M. Hirahara, M. Z. Ertem, M. Komi, H. Yamazaki, C. J. Cramer and M. Yagi, Inorg. Chem., 2013, 52, 6354-6364; (c) M. Hirahara, S. Nagai, K. Takahashi, K. Saito, T. Yui and M. Yagi, Inorg. Chem., 2015, 54, 7627-7635; (d) K. Takahashi, X. Zhang, M. Hirahara, T. Sato, K. Saito, T. Yui and M. Yagi, J. Photochem. Photobiol., A, 2015, 313, 117-125.

12 M. Hirahara, H. Tomoya, A. B. League, M. Z. Ertem, K. Takahashi, S. Nagai, K. Inaba, H. Yamazaki, K. Saito, T. Yui, C. J. Cramer and M. Yagi, Eur. J. Inorg. Chem., 2015, 2015, 3892-3903.

13 (a) S. W. Gersten, G. J. Samuels and T. J. Meyer, J. Am. Chem. Soc., 1982, 104, 4029-4030; (b) T. Wada, K. Tsuge and K. Tanaka, Angew. Chem., Int. Ed., 2000, 39, 1479-1482; (c) C. Sens, I. Romero, M. Rodriguez, A. Llobet, T. Parella and J. Benet-Buchholz, J. Am. Chem. Soc., 2004, 126, 7798-7799; (d) R. Zong and R. P. Thummel, J. Am. Chem. Soc., 2005, 127, 12802-12803; (e) Y. Xu, A. Fischer, L. Duan, L. Tong, E. Gabrielsson, B. Åkermark and L. Sun, Angew. Chem., Int. Ed., 2010, 49, 8934-8937; (f) J. J. Concepcion, J. W. Jurss, J. L. Templeton and T. J. Meyer, J. Am. Chem. Soc., 2008, 130, 16462-16463; (g) M. Yagi, S. Tajima, M. Komi and H. Yamazaki, Dalton Trans., 2011, 40, 3802-3804; $(h)$ D. J. Wasylenko, C. Ganesamoorthy, B. D. Koivisto, M. A. Henderson and C. P. Berlinguette, Inorg. Chem., 2010, 49, 2202-2209; (i) S. Masaoka and K. Sakai, Chem. Lett., 2009, 38, 182-183; (j) J. L. Boyer, D. E. Polyansky, D. J. Szalda, R. Zong, R. P. Thummel and E. Fujita, Angew. Chem., Int. Ed., 2011, 50, 12600-12604.

14 S. Tanaka, K. Takahashi, M. Hirahara, M. Yagi and K. Onda, J. Photochem. Photobiol., A, 2015, 313, 87-98.

15 M. Hirahara, A. Tsukamoto, H. Goto, S. Tada, M. Yagi and Y. Umemura, Chem.-Eur. J., 2016, 22, 2590-2594.

16 Y. Jahng, R. P. Thummel and S. G. Bott, Inorg. Chem., 1997, 36, 3133-3138.

17 M. H. V. Huynh, J. M. Lasker, M. Wetzler, B. Mort, L. F. Szczepura, L. M. Witham, J. M. Cintron, A. C. Marschilok, L. J. Ackerman, R. K. Castellano, 
D. L. Jameson, M. R. Churchill, A. J. Jircitano and K. J. Takeuchi, J. Am. Chem. Soc., 2001, 123, 8780-8784.

18 (a) A. Bahreman, B. Limburg, M. A. Siegler, R. Koning, A. J. Koster and S. Bonnet, Chem.-Eur. J., 2012, 18, 1027110280; (b) A. Bahreman, B. Limburg, M. A. Siegler, E. Bouwman and S. Bonnet, Inorg. Chem., 2013, 52, 94569469.

19 A. L. Spek, A. Gerli and J. Reedijk, Acta Crystallogr., Sect. C: Cryst. Struct. Commun., 1994, 50, 394-397.

20 (a) N. Chanda, D. Paul, S. Kar, S. M. Mobin, A. Datta, V. G. Puranik, K. K. Rao and G. K. Lahiri, Inorg. Chem., 2005, 44, 3499-3511; (b) Z. Deng, H.-W. Tseng, R. Zong, D. Wang and R. Thummel, Inorg. Chem., 2008, 47, 18351848; (c) G. Sathyaraj, M. Kiruthika, T. Weyhermuller and B. U. Nair, Dalton Trans., 2012, 41, 8460-8471.

21 S. Bonnet, J.-P. Collin and J.-P. Sauvage, Inorg. Chem., 2007, 46, 10520-10533.

22 B. P. Sullivan, J. M. Calvert and T. J. Meyer, Inorg. Chem., 1980, 19, 1404-1407.

23 M. J. Frisch, G. W. Trucks, H. B. Schlegel, G. E. Scuseria, M. A. Robb, J. R. Cheeseman, G. Scalmani, V. Barone,
B. Mennucci, G. A. Petersson, H. Nakatsuji, M. Caricato, X. Li, H. P. Hratchian, A. F. Izmaylov, J. Bloino, G. Zheng, J. L. Sonnenberg, M. Hada, M. Ehara, K. Toyota, R. Fukuda, J. Hasegawa, M. Ishida, T. Nakajima, Y. Honda, O. Kitao, H. Nakai, T. Vreven, J. A. Montgomery Jr, J. E. Peralta, F. Ogliaro, M. J. Bearpark, J. Heyd, E. N. Brothers, K. N. Kudin, V. N. Staroverov, R. Kobayashi, J. Normand, K. Raghavachari, A. P. Rendell, J. C. Burant, S. S. Iyengar, J. Tomasi, M. Cossi, N. Rega, N. J. Millam, M. Klene, J. E. Knox, J. B. Cross, V. Bakken, C. Adamo, J. Jaramillo, R. Gomperts, R. E. Stratmann, O. Yazyev, A. J. Austin, R. Cammi, C. Pomelli, J. W. Ochterski, R. L. Martin, K. Morokuma, V. G. Zakrzewski, G. A. Voth, P. Salvador, J. J. Dannenberg, S. Dapprich, A. D. Daniels, Ö. Farkas, J. B. Foresman, J. V. Ortiz, J. Cioslowski and D. J. Fox, Gaussian, Inc., Wallingford, CT, USA, 2009. 24 A. D. Becke, J. Chem. Phys., 1993, 98, 5648-5652. 25 C. Lee, W. Yang and R. G. Parr, Phys. Rev. B: Condens. Matter Mater. Phys., 1988, 37, 785-789. 